\title{
A STUDY OF LOAN COLOUR TERMS IN THE KOMI LANGUAGES
}

\author{
Elena Ryabina \\ University of Helsinki
}

\begin{abstract}
This article deals with a comparative study of loaned colour vocabulary in the closely related Komi-Zyrian and Komi-Permyak languages. Data were originally collected by using the field method suggested for establishing basic colour terms by Davies and Corbett $(1994,1995)$. Sixty-five coloured tiles were used as stimuli. The study explored and compared the psychological salience of recent Russian loan colour terms. It was found that loan colour words occurred more in the Komi-Permyak data. The most salient adopted colour term in the Komi-Permyak language is zelonej 'green'. In the next stage of basic colour system evolution in Komi-Zyrian and Komi-Permyak, the loan colour terms koričnevej 'brown', fioletovej 'purple' and oranževej 'orange' may appear. At the present stage of colour category development, the Russian basic terms rozovyj 'pink' and goluboj 'light-blue' are not salient in either language.
\end{abstract}

Keywords: loanword, basic colour term, psychological salience, Komi, KomiPermyak

DOI: http://dx.doi.org/10.12697/jeful.2014.5.2.05

\section{Introduction}

In this article, the Russian loanwords for colours in two closely related Komi languages are investigated. Komi is a pluricentric language with two standard language varieties, Komi-Zyrian and KomiPermyak. The Komi-Zyrian, or simply Komi, language is spoken mainly in the Republic of Komi in the Russian Federation. KomiPermyak is spoken in the Komi-Permyak Okrug of the Perm Krai. The Komi languages, together with Udmurt, belong to the Permian group of the Finno-Ugric languages.

The colour lexicons of the Komi and Komi-Permyak languages were studied in the framework of the theory of colour universals, which stems originally from Brent Berlin's and Paul Kay's famous monograph (1969). According to Berlin and Kay (1969: 2-5), all languages have between two and eleven basic colour categories, labelled with 
basic colour terms. A possible set of eleven basic colour categories becomes encoded in the history of a given language in a fixed chronological order (Berlin and Kay 1969). The evolution of the basic colour term system starts with two achromatic colour categories and passes through seven stages. The second to appear in a language in an evolutionary process is the colour category red, and then either yellow or green lexicalises. Yellow and green correspond to stages III and IV; they should appear in languages one by one in different sequences. The last to appear are the categories brown, purple, pink, orange and grey, although grey may appear earlier (Kay and McDaniel 1978).

The evolutionary model of basic colour terms has been revised by many researchers (for an overview, see Biggam 2012). Some scholars have studied the early stages of basic colour term evolution. In particular, Paul Kay (1975: 260-261) discovered that there was only one word for the yellow-green category in the Creek and Natchez languages ${ }^{1}$. An analogous phenomenon was found by Robert E. MacLaury (1987) in the Shuswap language ${ }^{2}$. The data of the World Color Survey ${ }^{3}$ also showed infrequent occurrences of the yellow-green category in world languages. Kay, Berlin and Merrifield (1991: 18-20) argue that languages containing the category yellow-green have only four or five basic colour terms, and thus correspond to stages III or IV.

In recent studies, three kinds of universal colour categories are recognized: primary, composite and derived (Kay and McDaniel 1978, Kay and Maffi 2009). The first to appear in a language are the six primary colours - black, white, red, green, yellow and blue - and the last to appear are the derived colours: brown, purple, pink, orange and grey. Derived colours are mixtures of the primary colours; for example, orange is a mixture of red and yellow. Composite colours consist of fuzzy unions of primary colours, and they indicate the earliest stages of development, where the primary category has not yet reached the status of a separate term.

It is interesting to note that in the contemporary Komi and KomiPermyak languages there are several names for yellow and green, since the earlier names for yellow and green, viž and $v e \check{z}$, were presumably not differentiated. The folklorist Oleg Uljašev argues that in the oral tradition of poetry in Komi, no special significance was attached to

Creek is a Muskogean language, and Natchez is spoken by indigenous American peoples. Shuswap is spoken mainly in the central and southern interior of British Columbia, Canada.

3 Data from 111 languages in the World Color Survey. 
green, and the semantics of green in Komi changed under the influence of colour perception in Russian (Uljašev 1999: 24-26).

F. J. Wiedemann (1880) recorded in his Komi-German dictionary the Komi-Zyrian words viž and vež as 'yellow, green' and 'green, yellow', respectively. According to the etymological Komi dictionary, $v i z ̌$ means 'yellow, green' and vež means 'green' (Lytkin and Guljaev 1970: 49). In the Komi-Russian dictionary (Beznosikova et al. 2000), the following meanings of the word viz are given: 1) 'yellow', 2) 'yolk', 3) 'bile' and 4) 'green' (used in dialects). The word vež has the following meanings: 1) 'green', 2) 'green, immature, unripe', 3) 'light, golden' and 4) 'yellow'.

According to the Komi-Permyak-Russian dictionary (Batalova and Krivoščëkova-Gantman 1985: 60, 72, 148), vež is recorded first as 'yellow', and then as 'green' (as an archaic word). The word viž means 'green' in the northern dialect, and in the southern dialect it means 'yellow'. The Russian loanword zelonej means 'green'.

In the Komi language, the colour terms kolkviž and turunviž, which respectively mean 'colour of an egg yolk' and 'green grass', have apparently acquired the meaning of yellow and green recently (Rakin 1990: 119). In the words kolkviz 'yellow' and turunviz 'green', which are both compounds, the word viz is used as the second part. In the experimental study of Komi basic colour terms, subjects also used viž in compounds occurring as colour terms denoting green or yellow (Ryabina 2011a, 2011b).

The basic colour terms in this study were distinguished according to the definition given by Berlin and Kay (1969: 6-7), which includes four main criteria and four subsidiary criteria for a colour term to be basic:

"(i) It is monolexemic; that is, its meaning is not predictable from the meaning of its parts.

(ii) Its signification is not included in that of any other colour term.

(iii) Its application must not be restricted to a narrow class of objects.

(iv) It must be psychologically salient for subjects. Indices of psychological salience include, among others, (1) a tendency to occur at the beginning of elicited lists of colour terms, (2) stability of reference across subjects and across occasions of use, and (3) occurrence in the idiolects of all subjects.

These criteria (i-iv) suffice in nearly all cases to determine the basic colour terms in a given language. The few doubtful cases that arise are handled by the following subsidiary criteria: 
(v) The doubtful form should have the same distributional potential as the previously established basic terms.

(vi) Colour terms that are also the name of an object characteristically having that colour are suspect.

(vii) Recent foreign loanwords may be suspect.

(viii) In cases where lexemic status is difficult to access [see criterion (1)], morphological complexity is given some weight as a secondary criterion."

The author of the article previously studied the basic colour terms in Permian languages (Ryabina 2011a: 96-108). The primary basic colour terms, with the exception of the colour term for white, have common origins in the Komi, Komi-Permyak and Udmurt languages. Intriguingly, the names for white differ in all three languages. Some of the derived basic colour terms were shaped using language resources, while others were borrowed from different sources, e.g. Udmurt borrowed from the Russian and Turkic languages, and Komi from Russian.

The basic colour terms in Komi and Komi-Permyak are, respectively, geverd 'red', lęz 'blue', śę 'black', ješĭd 'white', turunviž 'green', kolkviž 'yellow' and rud 'grey' (Ryabina 2011a, 2011b), and gerd 'red', ćoćkom 'white', lęz 'blue', śę 'black', vež 'yellow' and zelonej 'green' (Ryabina, forthcoming). So the colour terms gerd 'red', lezz 'blue' and séd 'black' are identical words in Komi and Komi-Permyak. The words turunviž 'green', koĺkviž 'yellow', and vež 'yellow' have common origins, since in the compounds turunviž and kolkviž the word viž is used as the second part.

The aim of this paper is to compare the psychological salience of Russian loan colour terms in the Komi and Komi-Permyak languages. Russian has 12 basic colour terms, which is exceptional in that there are two terms to denote blue (Berlin and Kay 1969; Davies and Corbett 1994; Paramei 2005). According to Davies and Corbett (1994), the Russian basic colour terms are čërnyj 'black', belyj 'white', krasnyj 'red', zelënyj 'green', žëltyj 'yellow', sinij 'blue', goluboj 'light blue', koričnevyj 'brown', fioletovyj 'purple', rozovyj 'pink', oranževyj 'orange' and seryj 'grey'.

It is interesting to consider the Russian word zelonej 'green' in Komi-Permyak. The subsidiary criteria to determine the basic colour terms include doubt about recent foreign loanwords (Berlin and Kay 1969: 6-7); therefore, in the discussion part we will examine this colour term. 
The data collection was carried out according to the fieldwork method for establishing the basic colour terms of a language described by Davies and Corbett (Davies and Corbett 1994, 1995).

\section{Two case studies}

Fifty-one Komi (Komi-Zyrian) speakers (37 female and 14 male) between 11-81 years (mean age 49.4 years) were interviewed in Syktyvkar, Vizinga and the Kortkerossky and Koygorodsky Districts of the Republic of Komi in 2008-2009. Twenty-eight Komi-Permyak speakers (22 female and six male), between 20-90 years (mean age 43.25) were interviewed in Kudymkar and the Jusvinsky District of the Komi-Permyak Okrug of the Perm Krai in 2013.

\subsection{Methods}

The empirical method designed by Davies and Corbett (1995: 27) mainly takes into account the criteria of psychological salience in the definition of the basic colour terms. This method consists of two parts.

The list task. The subjects were requested to list as many colour names as they knew in their native language. All answers were written down in a diary in columns. In this part, we considered two criteria of psychological salience: frequency (the occurrence of a colour term in the idiolects of subjects) and mean position (the tendency of a colour term to occur at the beginning of elicited lists) (Davies and Corbett 1995: 27; Sutrop 2001: 266-267). Since the correlation between frequency and mean rank of a term is not always ideal, the list task method was complemented by Urmas Sutrop's (2001) use of a formula for calculating cognitive salience index (S) that integrates the two list task parameters:

$$
\mathrm{S}=\mathrm{F} /(\mathrm{N} \times \mathrm{mP}),
$$

where $\mathrm{F}$ is the frequency of the colour term in the list task, $\mathrm{mP}$ is the mean position in which the term is named, and $\mathrm{N}$ is the number of subjects. If all subjects have named a term $(\mathrm{F}=\mathrm{N})$ and the mean position of that term is 1 , then the salience (S) is also 1 for that term. The 
cognitive salience index can vary between 1 and 0 . It can be used to calculate the hierarchical ranking of colour terms or random listing data.

Colour vision. Two types of colour vision tests were used. The colour vision of Komi subjects was verified by the use of The City University Color Vision Test (Fletcher 1980). This is a simple test that does not require much time; it is used to detect symptoms of abnormal colour vision. The test is carried out in the following way: subjects are shown ten black tiles each having a coloured spot in the middle and four other spots of different tones of colour around the central spot. Subjects are asked which of the four spots (upper, lower, left or right) is the best match for the colour of the central spot.

The Komi-Permyak subjects were tested by using a colour vision test developed by Waggoner (2002). This is a white booklet consisting of nine plates in which six plates test for red-green colour vision deficiencies, one of the plates tests for the type and degree of red-green deficiency, and an additional plate tests for blue-yellow colour deficiency. Subjects were asked to name the numbers seen on the plates.

The colour-naming task. The subjects were asked to name colour tiles. Sixty-five coloured tiles were shown to the subjects in random order, and their task was to name each tile. The tiles were placed on a grey background. The subjects were allowed to omit tiles they found difficult to name. The experiment was carried out indoors in natural daylight, avoiding direct sunlight or shadow. All responses of the subjects were recorded. In this task, we took into account the agreement or consensus across the language speakers on the naming of colour tiles, which corresponds to the second and third criteria of psychological salience (Davies and Corbett 1995: 27; Sutrop 2002: 34).

Stimuli. The set of stimuli used in the colour-naming task consisted of 65 wooden tiles $(5 \times 5 \mathrm{~cm})$ covered with paper in colours selected from the Color-aid Corporation range of colours, which is based on Ostwald's colour system. Justification for the selection of the 65 colour samples is given in Davies et al. (1992: 1097-1100).

Ostwald's colour system. In Ostwald's colour system, the main features of colour are colour tone, i.e. hue, content of white, i.e. tint (T), and content of black or blackness, i.e. shade (S). The grey colour system is also divided into eight grades, according to the white and black content. Color-aid uses a modification of the Ostwald colour system, 
in which there are 24 chromatic colours: the six basic colours (abbreviated as $\mathrm{Y}$ - yellow, $\mathrm{O}$ - orange, $\mathrm{R}$ - red, $\mathrm{V}$ - violet, $\mathrm{B}$ - blue and $\mathrm{G}-$ green), and their transition tones with their respective codes, e.g. $\mathrm{YO}-$ yellow-orange and YOY - yellow-orange-yellow. Each colour shade is divided into four light variants, T1-T4, in which the amount of white increases proportionally, and three dark variants, S1-S3, where the amount of black increases. In addition, some extra-system colours, such as Sienna and Rose Red are used. Color-aid codes, as well as CIE coordinates (Commission Internationale de l'Eclairage) of colour tiles used in the experiment are available in the study by Davies and Corbett (1992: 1098-1099 and 1994: 70-71).

\section{Results}

In two experiments, Komi subjects named 3733 colour terms, and among them were 514 different terms. Komi-Permyak subjects named 2049 colour terms, among which 387 terms were different. During the two experiments, the subjects named different colour terms that came to mind, including specific, modified and compound terms. Russian loan colour words in modified compound terms (e.g. Komi pemidkoričnevej and Komi-Permyak pemit-zelonej) were not considered in this study. Since in the study a statistical data analysis was conducted, all answers were spelled according to the rule of standard languages. For example, speakers of the central dialects of the Komi-Permyak language pronounced the colour term lezz 'blue' as vez, due to the shift of the consonant $l$ to $v$.

\subsection{List task results}

In the list task, the Komi subjects offered 612 answers, among which were 109 different colour names. The Komi-Permyak subjects named 284 colour terms, among which were 69 different ones. The average number of colour terms named by the subjects was 12 in the Komi group and ten in the Komi-Permyak group. The lists of colour terms ranged in length from five to 34 terms (Komi) and from six to 17 terms (Komi-Permyak).

Tables 1.1 and 1.2 show the frequency of Komi and KomiPermyak colour terms offered first by subjects in elicited lists. As seen from the tables, gerd 'red' was the most frequently first-offered colour 
term by speakers of both languages. It is interesting to note that in both tables (Tables 1.1 and 1.2) the four first-offered terms denote the same colours: white, blue, green and black. The words denoting white and green differ in Komi and Komi-Permyak: Komi jě̌̌id 'white', turunviž 'green', and Komi-Permyak č́č́kom 'white', zelonej 'green'. In the Komi-Permyak group, in addition to the loan colour word zelonej 'green', another term from Russian, bardovej 'claret', was named first by one subject. In the Komi group, there were no Russian loanwords mentioned first.

Table 1.1. The first-offered colour terms in the list task, Komi group.

\begin{tabular}{l|l|c|c|c}
\multicolumn{1}{c|}{ Term } & \multicolumn{1}{|c|}{ English gloss } & $\begin{array}{c}\text { Women } \\
(37)\end{array}$ & $\begin{array}{c}\text { Men } \\
(14)\end{array}$ & $\begin{array}{c}\text { Total } \\
(51)\end{array}$ \\
\hline gẹrd & red & 16 & 8 & 24 \\
\hline ješíd & white & 7 & 2 & 9 \\
\hline lęz & blue & 4 & 1 & 5 \\
\hline turunviž & green & 3 & 1 & 4 \\
\hline șed & black & 2 & 2 & 4 \\
\hline viž & yellow & 2 & 0 & 2 \\
\hline karaz "ej & dark-green & 1 & 0 & 1 \\
\hline koĺkviž & yellow & 1 & 0 & 1 \\
\hline pěžem jevv rẹma & milk heated in an oven & 1 & 0 & 1
\end{tabular}

Table 1.2. The first-offered colour terms in the list task, KomiPermyak group.

\begin{tabular}{l|l|c|c|c} 
Term & English gloss & $\begin{array}{c}\text { Women } \\
(22)\end{array}$ & $\begin{array}{c}\text { Men } \\
(6)\end{array}$ & $\begin{array}{c}\text { Total } \\
(28)\end{array}$ \\
\hline gerd & red & 11 & 3 & 14 \\
\hline ćoćkom & white & 6 & 0 & 6 \\
\hline lęz & blue & 1 & 1 & 2 \\
\hline zélonej & green & 1 & 1 & 2 \\
\hline śed & black & 1 & 1 & 2 \\
\hline bardovej & claret & 1 & 0 & 1 \\
\hline vež & yellow & 1 & 0 & 1
\end{tabular}


Tables 2.1 and 2.2 display the results obtained in the colour-listing task. In the tables, the colour terms are ranked according to the cognitive salience index (S). In addition, the naming frequency (F) and mean position $(\mathrm{mP})$ of the terms in the lists are indicated. Table 2.1 shows Komi colour terms offered by at least five subjects. The KomiPermyak colour terms presented in Table 2.2 were offered at least by three subjects.

The frequency columns in Tables 2.1 and 2.2 show that all subjects of both language groups named the term gerd 'red'. The other most frequently offered Komi colour terms were lęz 'blue', śęd 'black', ješid 'white', turunviž 'green' and rud 'grey' (see Table 2.1). In addition, the two terms kolkviž and viž denoting yellow were named by at least half of the subjects. Only 15 subjects offered both colour terms, while the other subjects named either kolkviž or viž. Although kolkviž had a higher frequency than viž, the old colour name viž occurred in the second rank according to mean position, while kolkviž occurred in the seventh rank. For comparison, the other old colour name vež 'green' was named by only seven subjects and it occurred in the 15th rank according to the mean position. The colour terms with high frequency also occurred at the beginning of the colour lists according to mean position, with the exception of rud 'grey'. According to the mean position, rud 'grey' was in the 11th rank; however, according to the cognitive salience index, it occurred in the eighth rank.

The most salient Komi colour terms according to the cognitive salience index were gerd 'red', lęz 'blue', śę 'black', ješid 'white', turunviž 'green', viž 'yellow', kolkviž 'yellow' and rud 'grey'. The colour term rud 'grey' is an early loanword from Russian. There are only two recent Russian loanwords, alej 'pink' $(\mathrm{F}=13, \mathrm{mP}=8.92)$ and koričnevej 'brown' $(\mathrm{F}=11, \mathrm{mP}=7.73)$, in the list (see Table 2.1), which were in the 10th and 11th ranks, respectively, according to the cognitive salience index.

From Table 2.2 it is clear that the six Komi-Permyak primary basic colour terms, geved 'red', čoćkom 'white', lęz 'blue', śéd 'black', vež 'yellow' and zelonej 'green', had both the highest frequency and mean position. Among them was the recent Russian loanword zelonej 'green', which was the least salient primary colour term. This colour term was named by 20 subjects and it occurred in the fifth rank according to mean position. As is shown in Table 2.2, only four subjects mentioned the colour term viž, which means both yellow and green. As in the case of the Komi colour-term ranking, the primary basic colour terms 
100 Elena Ryabina

were followed by rud 'grey', although in the Komi-Permyak group it was not salient as it was named by only 11 people.

Table 2.1. Ranking order of the colour terms offered by Komi speakers in the list task.

\begin{tabular}{|c|c|c|c|c|c|c|c|}
\hline Term & Gloss & $\begin{array}{c}\text { Fre- } \\
\text { quency }\end{array}$ & Rank & $\begin{array}{c}\text { Mean } \\
\text { position }\end{array}$ & Rank & Salience & Rank \\
\hline gerd & red & 51 & 1 & 2.59 & 1 & 0.386 & 1 \\
\hline legz & blue & 50 & 2.5 & 3.98 & 3 & 0.246 & 2 \\
\hline séd & black & 50 & 2.5 & 4.88 & 5 & 0.2 & 3 \\
\hline ježid & white & 49 & 4 & 5.12 & 6 & 0.187 & 4 \\
\hline turunviž & green & 45 & 5 & 4.87 & 4 & 0.181 & 5 \\
\hline$v i z ̌ z$ & yellow & 27 & 8 & 3.92 & 2 & 0.135 & 6 \\
\hline kolíkviž & yellow & 36 & 7 & 5.47 & 7 & 0.129 & 7 \\
\hline rud & grey & 42 & 6 & 7.95 & 11 & 0.103 & 8 \\
\hline kelidlegz & light-blue & 15 & 9 & 9.6 & 14 & 0.03 & 9 \\
\hline alej & pink & 13 & 11.5 & 8.92 & 13 & 0.028 & 10 \\
\hline koričnevej & brown & 11 & 14 & 7.73 & 10 & 0.028 & 11 \\
\hline pemidlez & dark-blue & 14 & 10 & 11.43 & 17 & 0.024 & 12 \\
\hline jugidlegz & light-blue & 13 & 11.5 & 11.77 & 19 & 0.022 & 13 \\
\hline karaz"ej & dark-green & 7 & 17.5 & 6.43 & 8 & 0.021 & 14 \\
\hline pemidgerd & dark-red & 12 & 13 & 11.67 & 18 & 0.02 & 15 \\
\hline mugem & brown & 9 & 16 & 8.78 & 12 & 0.02 & 16 \\
\hline jugidgerd & light-red & 10 & 15 & 12.4 & 20 & 0.016 & 17 \\
\hline$v e \check{z}$ & green & 7 & 17.5 & 10.43 & 15 & 0.013 & 18 \\
\hline alejgerd & pink & 5 & 20 & 7.6 & 9 & 0.013 & 19 \\
\hline kelidgerd & light-red & 6 & 19 & 10.5 & 16 & 0.011 & 20 \\
\hline čim gerd & pure-red & 6 & 19 & 14 & 21 & 0.008 & 21 \\
\hline pemidrud & dark-grey & 5 & 20 & 16 & 22 & 0.006 & 22 \\
\hline zarni & golden & 6 & 19 & 19.83 & 23 & 0.006 & 23 \\
\hline eziś & silver & 5 & 20 & 20.8 & 24 & 0.005 & 24 \\
\hline
\end{tabular}


Table 2.2. Ranking order of the colour terms offered by KomiPermyak speakers in the list task.

\begin{tabular}{|c|c|c|c|c|c|c|c|}
\hline Term & Gloss & $\begin{array}{c}\text { Fre- } \\
\text { quency }\end{array} \mid$ & Rank & $\begin{array}{c}\text { Mean } \\
\text { position }\end{array}$ & Rank & Salience & Rank \\
\hline gerd & red & 28 & 1 & 1.86 & 1 & 0.538 & 1 \\
\hline č́oćkom & white & 25 & 5 & 3.16 & 2 & 0.282 & 2 \\
\hline legz & blue & 26 & 4 & 3.61 & 3 & 0.257 & 3 \\
\hline séd & black & 27 & 2.5 & 4.07 & 4 & 0.237 & 4 \\
\hline$v e \check{z}$ & yellow & 27 & 2.5 & 4.33 & 5 & 0.223 & 5 \\
\hline zeĺonej & green & 20 & 6 & 5 & 6 & 0.143 & 6 \\
\hline rud & grey & 11 & 7 & 7.54 & 10 & 0.052 & 7 \\
\hline koričnevej & brown & 6 & 9 & 8 & 13.33 & 0.027 & 8 \\
\hline golubej & light-blue & 7 & 8 & 10 & 21 & 0.025 & 9 \\
\hline fioletovej & purple & 5 & 10.5 & 7.2 & 7 & 0.025 & 10 \\
\hline śera & grey & 5 & 10.5 & 7.8 & 12 & 0.023 & 11 \\
\hline oranževej & orange & 4 & 12 & 7.75 & 11 & 0.018 & 12 \\
\hline$v i \check{z}$ & green & 4 & 12 & 8 & 13.33 & 0.018 & 13 \\
\hline rozovej & pink & 4 & 12 & 8.25 & 16 & 0.017 & 14 \\
\hline malinovej & crimson & 4 & 12 & 9.25 & 18 & 0.015 & 15 \\
\hline jugit-lezz & light-blue & 4 & 12 & 9.5 & 19 & 0.015 & 16 \\
\hline vež-gerd & yellow-red & 3 & 13 & 7.33 & 8.5 & 0.015 & 17 \\
\hline murema & brown & 3 & 13 & 7.33 & 8.5 & 0.015 & 18 \\
\hline śerej & grey & 3 & 13 & 8 & 13.33 & 0.013 & 19 \\
\hline gevd-vež & red-yellow & 4 & 12 & 11 & 24 & 0.013 & 20 \\
\hline sireńevej & $\begin{array}{l}\text { mauve, } \\
\text { lilac }\end{array}$ & 3 & 13 & 8.67 & 17 & 0.012 & 21 \\
\hline alej & pink & 3 & 13 & 9.67 & 20 & 0.011 & 22 \\
\hline $\begin{array}{l}\text { pemit- } \\
\text { gerd }\end{array}$ & dark-red & 3 & 13 & 10.33 & 22 & 0.01 & 23 \\
\hline pemit-lez & dark-blue & 3 & 13 & 10.67 & 23 & 0.01 & 24 \\
\hline
\end{tabular}

Overall, in the Komi-Permyak colour list more recent Russian loanwords occurred. For example, as Table 2.2 shows , rud 'grey' was followed by koričnevej 'brown' $(\mathrm{F}=6, \mathrm{mP}=8)$, golubej 'light-blue' $(\mathrm{F}=7, \mathrm{mP}=10)$, fioletovej 'purple' $(\mathrm{F}=5, \mathrm{mP}=7.2)$ and sera 'grey' (from Russian seryj 'grey') ( $\mathrm{F}=5, \mathrm{mP}=7.8)$. At least four subjects named the terms oranževej 'orange' $(\mathrm{mP}=7.75)$, rozovej 'pink' $(\mathrm{mP}=$ 
8.25) and malinovej 'crimson, raspberry pink' $(\mathrm{mP}=9.25)$, and three subjects named the terms śerej 'grey' $(\mathrm{mP}=8)$, sireńevej 'mauve, lilac' $(\mathrm{mP}=8.67)$ and alej 'pink' $(\mathrm{mP}=9.67)$.

\subsection{The colour-naming task}

The number of possible responses was 3315 in the Komi group and 1820 in the Komi-Permyak group (65 tiles $\times$ number of subjects); Komi speakers omitted naming stimuli 194 times and Komi-Permyak speakers 55 times. Komi subjects gave to the colour stimuli 481 and Komi-Permyak subjects 366 different colour names. The percent of missing answers was 5.8\% in the Komi group and 3\% in the KomiPermyak group. It should be stressed that linguists omitted more answers than other subjects in the Komi-Permyak group, while in the Komi group linguists produced more colour words. This was because the Komi-Permyak linguists tended to avoid Russian words, while the other subjects offered a lot of borrowed colour names.

Tables 3.1 and 3.2 show the most frequent colour terms with their total frequencies (Tf), dominance frequencies (Df), number of tiles for which these were named at least once $\left(\sum \mathrm{CS}\right)$, and the frequency/tile ratio $\left(\mathrm{Tf} / \sum \mathrm{CS}\right)$.

The most frequent Komi colour terms ( $\mathrm{Tf}>86)$ were turunviž 'green', lęz 'blue', geverd 'red', korič́nevej 'brown', rud 'grey', ješ̌̉id 'white', fioletovej 'purple', śed 'black' and kolkviž 'yellow', as shown in Table 3.1. The colour name viž 'yellow' occurred less often in the second experiment, although it was a salient colour term according to the results of the first experiment. The two loan colour terms koričnevej 'brown' and fioletovej 'purple' had the highest total frequency. The other colour terms from Russian, oranževej 'orange', rozovej 'pink', alej 'pink' and sireńevej 'mauve, lilac', had lower frequencies. It should be emphasized that in the colour-naming task rozovej 'pink' had a higher frequency than alej 'pink', which was mentioned more in the list task.

Among the most frequent Komi-Permyak colour terms ( $\mathrm{Tf}>48)$, there were four Russian loan words, zelonej 'green', fioletovej 'purple', koričnevej 'brown' and rozovej 'pink', as is shown in Table 3.2. Of these, the colour name zelonej 'green' was the most frequent colour term. The most frequent terms were followed by the loan colour names malinovej 'crimson, raspberry pink', oranževej 'orange', śerej 'grey', golubej 'light-blue' and sireńevej 'mauve', which were also named in 
the list task; those colour names scored higher than the earlier loan colour term rud 'grey'. A few subjects also named the loan colour terms alej 'pink', bir 'uzovej 'turquoise', śera 'grey', beževej 'beige', lilovej 'violet' or salatnej 'lettuce green'.

The colour terms that were used for a given tile by at least half of the subjects had dominance frequency, which means the dominance index (DI) was $\geq 1 / 2$. In the Komi group, the colour terms koričnevej 'brown' and fioletovej 'purple' were not attributed to one dominant colour tile, although they had high total frequency (Table 3.1). On the other hand, the colour name with low total frequency oranževej 'orange' was the dominant term for the OYO colour tile. Dominance frequency is a stringent criterion for a colour term to be basic, although the term oranževej 'orange' is not included in the list of basic colour terms of the Komi language (for more details, see Ryabina 2011a, 2011b). This colour term was not dominant during the expedition in 2008. In 2009 subjects from the Koygorodsky District, where the influence of Russian language is evident, were interviewed.

In the Komi-Permyak group all of the colour names with high frequency were considered to be dominant terms, with the exception of the colour name rozovej 'pink' (see Table 3.2). The loan colour words koričnevej 'brown' and fioletovej 'purple' corresponded to RO S3 and YO S3, and VBV, VRV and V, respectively. In addition, the colour names oranževej 'orange' and śerej 'grey' were named by most of the subjects for the OYO, O and GRAY 6 tiles, respectively. Altogether, there were five Russian colour terms with high dominance frequency in the Komi-Permyak group.

In the last column of Tables 3.1 and 3.2, the frequency/tile ratio, indicating the consensus of use of a term among the subjects, is shown. The higher the ratio, the greater degree of consensus. In both languages, the greatest consensus among subjects was achieved by the six primary colour terms and koričnevej 'brown'. 
104 Elena Ryabina

Table 3.1. The most frequent colour terms offered by Komi speakers in the tile-naming task.

\begin{tabular}{|c|c|c|c|c|c|}
\hline Term & Gloss & $\mathbf{T f}$ & Df & $\sum \mathrm{CS}$ & $\mathrm{Tf} / \sum \mathrm{CS}$ \\
\hline turunviž & green & 181 & 34 & 15 & 12.07 \\
\hline legz & blue & 174 & 117 & 15 & 11.60 \\
\hline gerd & red & 139 & 72 & 10 & 13.90 \\
\hline koričnevej & brown & 119 & - & 9 & 13.22 \\
\hline rud & grey & 117 & 63 & 15 & 7.80 \\
\hline ježid & white & 103 & 47 & 11 & 9.36 \\
\hline fioletovej & purple & 97 & - & 13 & 7.46 \\
\hline séd & black & 91 & 85 & 5 & 18.20 \\
\hline koĺkviž & yellow & 90 & 58 & 9 & 10.00 \\
\hline jugidlęz & light-blue & 81 & - & 14 & 5.78 \\
\hline oranževej & orange & 80 & 27 & 11 & 7.27 \\
\hline jugid turunviž & light-green & 77 & - & 10 & 7.70 \\
\hline pemidlez & dark-blue & 76 & 27 & 11 & 6.91 \\
\hline pemid turunviž & dark-green & 66 & 28 & 10 & 6.60 \\
\hline rozovej & pink & 61 & - & 11 & 5.54 \\
\hline alej & pink & 59 & - & 17 & 3.47 \\
\hline sireńevej & mauve, lilac & 58 & - & 11 & 5.27 \\
\hline$v i \check{z}$ & yellow & 55 & - & 15 & 3.67 \\
\hline kelídlegz & light-blue & 53 & - & 11 & 4.82 \\
\hline jugidgerd & light-red & 44 & - & 11 & 4.00 \\
\hline kelidturunviž & light-green & 42 & - & 9 & 4.67 \\
\hline mugem & brown & 31 & - & 14 & 2.21 \\
\hline jugidrud & light-grey & 29 & - & 7 & 4.14 \\
\hline pemidrud & dark-grey & 26 & - & 7 & 3.71 \\
\hline jugidrozovej & light-pink & 25 & - & 8 & 3.12 \\
\hline karaz"ej & dark-green & 20 & - & 13 & 1.54 \\
\hline kelílvižz & light-yellow & 20 & - & 10 & 2.00 \\
\hline jugidkoričnevej & light-brown & 20 & - & 6 & 3.33 \\
\hline jugidviž & light-yellow & 19 & - & 13 & 1.46 \\
\hline jugid kolkviž & light-yellow & 18 & - & 6 & 3.00 \\
\hline
\end{tabular}


Table 3.2. The most frequent colour terms offered by the KomiPermyak speakers in the tile-naming task.

\begin{tabular}{|c|c|c|c|c|c|}
\hline Term & Gloss & Tf & Df & $\sum \mathrm{CS}$ & $\mathbf{T f} / \sum \mathbf{C S}$ \\
\hline zeĺonej & green & 103 & 51 & 14 & 7.36 \\
\hline legz & blue & 96 & 61 & 11 & 8.73 \\
\hline fioletovej & purple & 86 & 53 & 12 & 7.17 \\
\hline koričnevej & brown & 78 & 30 & 7 & 11.14 \\
\hline$v e \check{z}$ & yellow & 66 & 45 & 8 & 8.25 \\
\hline geverd & red & 61 & 42 & 6 & 10.17 \\
\hline śed & black & 60 & 49 & 6 & 10 \\
\hline rozovej & pink & 54 & - & 11 & 4.9 \\
\hline ćoćkom & white & 51 & 38 & 5 & 10.2 \\
\hline malinovej & crimson & 44 & - & 6 & 7.33 \\
\hline oranževej & orange & 44 & 28 & 7 & 6.28 \\
\hline śerej & grey & 43 & 14 & 11 & 3.9 \\
\hline golubej & light-blue & 39 & 9 & 9 & 4.33 \\
\hline sireńevej & mauve, lilac & 37 & 7 & 11 & 3.36 \\
\hline rud & grey & 35 & 9 & 11 & 3.18 \\
\hline jugit-zelonej & light-green & 28 & - & 6 & 4.67 \\
\hline svetlo-zelonej & light-green & 27 & - & 8 & 3.37 \\
\hline jugit-legz & light-blue & 26 & - & 8 & 3.25 \\
\hline pemit-zelonej & dark-green & 20 & - & 5 & 4 \\
\hline alej & pink & 19 & - & 12 & 1.58 \\
\hline bir"uzovej & turquoise & 17 & - & 6 & 2.83 \\
\hline pemit-legz & dark-blue & 17 & - & 4 & 4.25 \\
\hline jugit-vež & light-yellow & 15 & - & 6 & 2.5 \\
\hline jugit-gerd & light-red & 14 & - & 8 & 1.75 \\
\hline vež-gerd & yellow-red & 12 & - & 5 & 2.4 \\
\hline t"omno-zeĺonej & dark-green & 12 & - & 5 & 2.4 \\
\hline bledno-rozovej & pale-pink & 11 & - & 4 & 2.75 \\
\hline svetlo-sireńevej & light-lilac & 11 & - & 6 & 1.83 \\
\hline śera & grey & 11 & - & 8 & 1.37 \\
\hline beževej & beige & 10 & - & 7 & 1.43 \\
\hline lilovej & violet & 10 & - & 8 & 1.25 \\
\hline salatnej & lettuce green & 10 & - & 3 & 3.33 \\
\hline jugit-rud & light-grey & 10 & - & 6 & 1.67 \\
\hline svetlo-koričnevej & light-brown & 9 & - & 5 & 1.8 \\
\hline svetlo-rozovej & light-pink & 9 & - & 5 & 1.8 \\
\hline
\end{tabular}


One can consider the dominance frequency of a colour term at different levels of consensus. For example, if the dominance index is $\geq 1 / 4$, then at least $25 \%$ of subjects used the colour term for a given tile. In this article, the dominance frequencies of loan colour terms on the following threshold levels are considered.

$\begin{array}{lrrrrrr}\text { DI } & 1 / 10 & 1 / 4 & 1 / 3 & 1 / 2 & 2 / 3 & 3 / 4 \\ \text { Frequency pro tile (Komi) } \geq & 5 & 12 & 16 & 25 & 33 & 38 \\ \text { Frequency pro tile (Komi-Permyak) } \geq & 3 & 7 & 9 & 14 & 18 & 21\end{array}$

Tables 4.1 and 4.2 demonstrate the dominant colour terms at different consensus levels and the number of dominant tiles. There were 36 dominant tiles with seven adopted colour terms at the lowest consensus level (DI 1/10) in the Komi group (see Table 4.1). At the 25\% consensus level (DI 1/4), 14 dominant tiles corresponded to four colour terms. The 33\% threshold level (DI 1/3) was exceeded by three colour terms, oranževej 'orange', koričnevej 'brown' and fioletovej 'purple', but only oranževej 'orange' reached the $50 \%$ threshold (DI $1 / 2)$.

In the Komi-Permyak group, there were 16 dominant adopted colour terms corresponding to 64 tiles at the lowest consensus level (see Table 4.2). At the $25 \%$ consensus level, 36 dominant tiles corresponded to nine colour terms. The 33\% threshold level (DI 1/3) was reached by the terms zelonej 'green', fioletovej 'purple', koričnevej 'brown', oranževej 'orange', śerej 'grey', rozovej 'pink', malinovej 'crimson, raspberry pink' and golubej 'light-blue' 23 times. The 50\% threshold level was exceeded by the colour terms zelonej 'green', fioletovej 'purple', koričnevej 'brown', oranževej 'orange' and śerej 'grey' eleven times. Two colour names, zelonej 'green' and fioletovej 'purple', reached the $66 \%$ threshold (DI 2/3). 
Table 4.1. Dominant loan colour terms in the tile-naming task. Komi group.

\begin{tabular}{l|l|c|c|c|c|c|c}
\multicolumn{1}{c|}{ Term } & \multicolumn{1}{|c|}{ Gloss } & $\begin{array}{c}\text { DI } \\
\mathbf{1 / 1 0}\end{array}$ & $\begin{array}{c}\text { DI } \\
\mathbf{1 / 4}\end{array}$ & $\begin{array}{c}\text { DI } \\
\mathbf{1 / 3}\end{array}$ & $\begin{array}{c}\text { DI } \\
\mathbf{1 / 2}\end{array}$ & $\begin{array}{c}\text { DI } \\
\mathbf{2 / 3}\end{array}$ & $\begin{array}{c}\text { DI } \\
\mathbf{3 / 4}\end{array}$ \\
\hline oranževej & orange & 5 & 3 & 2 & 1 & 0 & 0 \\
\hline koričnevej & brown & 7 & 7 & 4 & 0 & 0 & 0 \\
\hline fioĺetovej & purple & 5 & 3 & 3 & 0 & 0 & 0 \\
\hline rozovej & pink & 5 & 1 & 0 & 0 & 0 & 0 \\
\hline alej & pink & 6 & 0 & 0 & 0 & 0 & 0 \\
\hline sireńevej & mauve, lilac & 6 & 0 & 0 & 0 & 0 & 0 \\
\hline śerej & grey & 2 & 0 & 0 & 0 & 0 & 0
\end{tabular}

Table 4.2. Dominant loan colour terms in the tile-naming task. Komi-Permyak group.

\begin{tabular}{|c|c|c|c|c|c|c|c|}
\hline Term & Gloss & $\begin{array}{c}\text { DI } \\
1 / 10\end{array}$ & $\begin{array}{l}\text { DI } \\
1 / 4\end{array}$ & $\begin{array}{l}\text { DI } \\
1 / 3\end{array}$ & $\begin{array}{l}\text { DI } \\
1 / 2\end{array}$ & $\begin{array}{l}\text { DI } \\
2 / 3\end{array}$ & $\begin{array}{l}\text { DI } \\
3 / 4\end{array}$ \\
\hline zelonej & green & 10 & 8 & 4 & 3 & 1 & 0 \\
\hline fioletovej & purple & 7 & 5 & 3 & 3 & 1 & 0 \\
\hline koričnevej & brown & 7 & 7 & 6 & 2 & 0 & 0 \\
\hline oranževej & orange & 4 & 3 & 2 & 2 & 0 & 0 \\
\hline śerej & grey & 4 & 3 & 2 & 1 & 0 & 0 \\
\hline rozovej & pink & 7 & 3 & 2 & 0 & 0 & 0 \\
\hline malinovej & crimson & 5 & 3 & 3 & 0 & 0 & 0 \\
\hline golubej & light-blue & 6 & 2 & 1 & 0 & 0 & 0 \\
\hline sireńevej & mauve, lilac & 5 & 2 & 0 & 0 & 0 & 0 \\
\hline alej & pink & 2 & 0 & 0 & 0 & 0 & 0 \\
\hline bir"uzovej & turquoise & 2 & 0 & 0 & 0 & 0 & 0 \\
\hline śera & grey & 0 & 0 & 0 & 0 & 0 & 0 \\
\hline beževej & beige & 1 & 0 & 0 & 0 & 0 & 0 \\
\hline lilovej & violet & 1 & 0 & 0 & 0 & 0 & 0 \\
\hline salatnej & lettuce green & 2 & 0 & 0 & 0 & 0 & 0 \\
\hline bolotnej & marsh & 1 & 0 & 0 & 0 & 0 & 0 \\
\hline
\end{tabular}




\section{Discussion}

This paper deals with a comparative study of loan colour vocabulary in the closely related Komi-Zyrian and Komi-Permyak languages. The work explores and compares the psychological salience of recent Russian loan colour terms.

Interviews with language speakers were carried out in two stages. The content of two experimental tasks was comparable with the language situation of the Permian languages ${ }^{4}$. For example, in the first task subjects had to name as many colour names as they knew in their native language and they gave answers in carefully chosen words, avoiding Russian examples. In the same way, a student or journalist tries not to use many Russian words in her or his essay or article written, for example, in the Komi language. Likewise, in giving an interview on TV or radio one tries to speak pure Komi as much as possible. However, in everyday situations speakers of Permian languages use a lot of Russian words in their speech. The second experimental task, i.e. the colour-naming task, resembled a practical conversational situation since the subjects had not only to recollect Komi colour words, but to name 65 concrete colour stimuli. Therefore, in the second task, the number of Russian colour terms was greater.

Paul Kay (1975: 263-269) has formulated the following predictions about change in synchronic basic colour lexicons. In his opinion, there is inter-speaker variation in a language in which the colour term system is undergoing change. There is minimal inter-speaker variation in some languages and considerable inter-speaker variation in other languages.

"a) The most salient secondary color terms will be those that become basic at the next stages.

b) The relative degrees of salience of the secondary terms should follow the ordering of the predicted evolutionary sequence.

c) Not all speakers will be at the same stage with respect to basic color lexicon.

d) The totality of stages represented will be contiguous in the sequence.

e) Difficulties in classifying speakers as to stage will involve only stages adjacent in the sequence.

f) The basic color terms added at later stages are present as secondary terms for speakers at earlier stages.

On standard varieties of Permian languages, see Edygarova 2013a, 2013b. 
g) Stage of speaker will correlate with various social factors depending on the local social situation, but there should be a pervasive correlation with age."

The author of the article previously noted that differences of colour vocabulary by speakers of closely related Udmurt language depend on gender, age and occupation (Ryabina 2009). Most subjects in this study were speakers of the southern dialect of Udmurt, the basic colour lexicon of which corresponds to the last stage according to the hierarchical basic colour term sequence. The aim of the research was to explore the usage of either basic or specific colour names by subjects of different social categories. Occupation did not significantly influence the results of the older female respondents, but it was found to be a relevant factor for the male respondents. Male respondents who dealt with painting or the Udmurt language largely used specific colour terms, while other men mainly used basic colour terms. Older female respondents, compared to older male respondents and young respondents of both genders, offered more colour words. Older men named more specific terms than younger men. The least number of colour terms was produced by younger women. This can be explained by the language situation in the Udmurt Republic: younger people use the Udmurt language less than older people do.

In the current study, the colour vocabularies of Komi and KomiPermyak subjects depended on the sphere of activities of the subjects and they did not significantly correlate with age. Some Komi female subjects aged 45-46 knew more colour terms and they offered Komi colour names for derived colour categories. At the same time, there were other female subjects of the same age who produced even fewer colour names in Komi than did the younger subjects. In the KomiPermyak group, the colour vocabularies of subjects were correlated only with the occupations of the subjects. Linguists, journalists and teachers of Komi-Permyak knew colour terms fairly well compared to average speakers.

In the Komi group, the inter-speaker variation in basic colour lexicon was also connected to vernacular. For example, the Russian colour term oranževej 'orange' was not a dominant term in the second task for respondents from the Kortkerossky District and Vizinga in 2008, while most of the subjects from the Koygorodsky District chose this colour name for a concrete colour tile.

It is possible to give Komi or Komi-Permyak names to almost all 65 colour stimuli. For example, to denote different colour shades, e.g. 
hue, shadow, tint, intensity, darkness or lightness, one can use different morphological means and modifying adjectives. The absence of basic derived colour terms in the Komi languages doesn't indicate an inability to express those colours in their native language. For brown, orange and purple, speakers offered several names in their native language, although those colour names were not psychologically salient for speakers. Komi subjects offered the following names for brown: mugęm, mugov and mušì are derived words from mu 'earth', čaj rema means 'colour of tea', čaj viž means 'yellow like tea', and perkal is presumably derived from the word perk, which is recorded in the Komi-Russian Dictionary as 'Nucifraga caryocatactes' (Beznosikova et al. 2000), and in the etymological Komi dictionary as 'insect, louse' in the Izhemsky dialect (Lytkin and Guljaev 1970). For the colour orange, they offered different modifying adjectives, including stems of the words red and yellow, and for purple modifying adjectives, including stems of the words red and blue. In addition, the word lemrema 'the colour of bird cherry' was offered for the colour purple.

Komi-Permyak subjects who were philologists by education offered the word murema 'colour of the earth' for brown, gerd-vež 'red-yellow' or vež-gerd 'yellow-red' for orange, and ležz-gerd 'blue-red' and lemrem 'the colour of bird cherry' for purple. Nobody offered KomiPermyak words for pink. Moreover, some of the respondents in the "philologist" group, who had more difficulties in the tile-naming task, only omitted naming pink colour tiles.

Edygarova (2013a: 57 and 2013b: 15-16) has recently researched the Udmurt language varieties. She has estimated that only $7 \%$ of her research subjects tended to know the standard Udmurt language, i.e. those who were able to speak the pure Udmurt used in newspaper publishing or broadcasting, and avoided Russian loan words. The majority of Udmurts spoke vernacular forms. Among the $7 \%$ of subjects, there were Udmurts who dealt with the Udmurt language at a professional level, e.g. writers, journalists, researchers and teachers, as well as some students of the Udmurt language and superior high school students. One of the strategies of maintaining modern standard Udmurt language correction is language purism. However, in Edygarova's opinion, the use of assumed neologisms creates an artificial character of the language which is alien to speakers. In addition, limited broadcasting activities and vernacular school education make it difficult to disseminate language innovations.

The propaganda regarding language purism was successful at the beginning of the campaign against illiteracy and the language planning 
of the 1920s, when the majority of speakers of Permian languages spoke only their native languages. Returning to the results of colour vocabulary tasks, it seems that young Udmurt speakers tend to use Russian specific colour names while the majority of Komi speakers tend to use derived colour terms from Russian. However, in order to foster the usage of the native colour terms of Permian languages, it is possible to launch some interesting projects. For example, ethnic fashions could be developed and catalogues of fashionable clothes distributed.

The results of this study show that for Komi-Permyak speakers it is acceptable to use Russian words. Ten Russian loan colour terms were named in the list task. Moreover, the borrowed Russian word zelonej 'green' tended to occur relatively early in the lists. Zelonej 'green' occupied the last position among the six primary colour terms. On the other hand, the earlier Russian loanword rud 'grey' had a lower frequency in the Komi-Permyak group than in Komi. There were only two recently borrowed words from Russian offered by a few Komi subjects in the list task.

In spite of the fact that the average number of colour terms listed by Komi speakers was higher, they had more difficulties in the colournaming task. The percentage of omissions in the colour-naming task in the Komi-Permyak group was twice as low as in the Komi group. Moreover, some subjects with philological education in the KomiPermyak group gave fewer answers than other subjects. This can be explained by the fact that most Komi-Permyak subjects tended to use Russian colour names while specialists in the Komi-Permyak language avoided loanwords.

The naming task data of the Komi language contained more borrowed Russian words. The most salient among them were oranževej 'orange', koričnevej 'brown' and fioletovej 'purple'. In the first experiment, only koričnevej 'brown' was mentioned by 11 subjects. In the second experiment, koričnevej 'brown' and fioletovej 'purple' occurred among the seven most frequently used terms, though these were not used dominantly for any colour stimulus. Only the term oranževej 'orange' was used dominantly for one colour tile. It should be emphasized that during the second task the term rozovej was frequently offered by subjects for the colour pink, whereas in the first task word alej or the compound word alejgerd (alej 'pink', gerd 'red') were offered more often. Obviously, the word alej was borrowed from Russian earlier than rozovej. The subjects who named this colour term in the first task perceived it as a Komi word. Alej lenta is the title of the 
first Komi novel, written by Juhnin in 1939. This novel narrates the life of peasants in the early twentieth century. The subjects who remembered this novel named the word alej. In addition, alej occurred in the Komi-Permyak data. In the Russian-Komi dictionary, pink is recorded as alejgerd (Beznosikova et al. 2003). Alejgerd 'pink' had a very low frequency in both experiments.

Loan colour terms, which were listed in the first experiment by Komi-Permyak speakers, had high frequency in the second experiment. So, zelonej 'green', fioletovej 'purple' and koričnevej 'brown' scored equally high as the primary colour names lez 'blue', vež 'yellow', gerd 'red', śed 'black' and ćoćkom 'white'. The colour terms oranževej 'orange' and śerej 'grey' also occurred among the dominant terms.

The colour term rud 'grey' did not occur as a salient term for KomiPermyak speakers. Moreover, in the tile-naming task the recent loanword śerej 'grey' was used more frequently. The word rud was an early borrowing from Russian in the Old Komi language (Rakin 1990: 115). This result is similar to Komi data with regards to colour terms denoting the colour pink. The earlier borrowed words were mentioned in the list task, while in the tile-naming task subjects used recent loanwords more frequently. In addition, the Old Komi colour name viž 'yellow' was named more frequently in the list task than in the tile-naming task.

In the Komi-Permyak data, the most infrequent derived basic colour term from Russian is rozovej 'pink'. In the second experiment, it competed with the loan term malinovej 'crimson, raspberry pink'. The loan colour term golubej 'light-blue' was not psychologically salient for the respondents.

The process of adopting colour words in Komi languages has proceeded mainly according to the universal evolutionary model; however, the derived colour term rud 'grey' was borrowed before the differentiation of the yellow and green colour categories. Obviously, the colour terms yellow and green appeared during the period of independent development of the Komi and Komi-Permyak languages. In Komi, the yellow and green colour words were shaped using morphological means. In Komi-Permyak, the colour term for green was borrowed from the Russian language. The colour term rud 'grey' was apparently borrowed in an earlier period, since both languages have this term (see also Rakin 1990: 115). According to Wiedemann (1880), the word rud earlier meant 'brown' and 'grey'. A few subjects in both language groups used the word rud to denote brown tiles as well. Berlin and Kay have also indicated that in some languages the colour category grey may appear before stage VII. In the dialects of the Udmurt 
language, the corresponding colour terms are the six primary categories as well as grey (Ryabina 2011a: 71).

Of all the loan colour terms considered in this study, the KomiPermyak zelonej 'green' was the most salient term. In the list task, it occurred among the first-offered colour terms and it had high frequency and mean position. In the naming task, it was the most frequent colour term and it achieved high dominance frequency. Regardless of the fact that zelonej is a recent loanword, it can be included in the list of basic colour terms. According to Kay et al. (1991: 18-20), languages containing a yellow-green category have four or five basic colour terms. In contemporary Komi-Permyak, the old yellow-green composite colour category vež has developed a separate semantic meaning: yellow. As mentioned above, zelonej was the least salient among the six basic colour terms. Thus the basic colour term system of Komi-Permyak can be considered to be on the fifth stage. Besides the Russian loanword zelonej, there is no other term to denote the colour green in Komi-Permyak.

The other borrowings were salient only in the second experiment. It might be argued that koričnevej 'brown', fioletovej 'purple' and oranževej 'orange' will become basic in the Komi languages at the next stages. In Komi-Permyak, the basic colour term rud may be replaced by the Russian loanword serej in the future if the number of KomiPermyak native speakers drops.

Komi-Russian areal contacts have a thousand-year history, and a great number of Russian loanwords exist in the vocabularies of both languages. However, Komi-Permyak speakers use more words originating from Russian. Interestingly, the respondents from the southern Komi Republic, which is located near the Komi-Permyak Okrug, used more Russian words than subjects from the Kortkerossky, Ust'Kulomsky and Sysol'sky Districts of the Komi Republic. On the other hand, among the Udmurt language subjects, more Russian words were used by subjects from the northern Udmurt Republic, which is also located not far from Komi-Permyak Okrug.

\section{Conclusion}

The results of the research show that there are more Russian loanwords in Komi-Permyak than in Komi-Zyrian. Several explanations account for that phenomenon. First of all, it may be supposed that Komi-Russian contacts began in the southern territories of Komi tribes earlier than in the north. Secondly, the Komi-Permyak Okrug is a part 
of the Perm Krai, whereas Komi-Zyrians have their own republic within the Russian Federation. So, broadcasting activities, newspapers and vernacular school education in the native language is more limited in the Komi-Permyak Okrug. Unfortunately, the process of Russianization has also had a strong effect on Komi-Zyrians.

According to the cognitive salient index, the most salient adopted colour term in the Komi-Permyak language was zelonej 'green', which can be included in the list of basic colour terms as a domesticated word. The subjects of Komi languages used both native colour terms and Russian colour terms in parallel. However, it seems that the loan colour words were used more frequently than the native words. In the next stage of basic colour system evolution in Komi and Komi-Permyak, koričnevej 'brown', fioletovej 'purple' and oranževej 'orange' may become conceptualised.

The subjects of this study were inclined to use recent loan terms in the second task of the experiment instead of Old Russian loanwords. So, rud 'grey' is not salient in the synchronic basic colour system of KomiPermyak, and the Russian basic colour term śerej 'grey' may replace the Komi-Permyak rud 'grey' in the near future.

At the present stage of colour category development, the Russian basic terms rozovyj 'pink' and goluboj 'light-blue' are not salient in either language. It appears that the pink colour category has not appeared yet in Komi-Permyak, since subjects did not offer KomiPermyak names for this colour.

\section{Acknowledgements}

The Komi data was gathered with the partial support of the Estonian Science Foundation grant nr. 8168 (awarded to Mari Uusküla for the years 2010-2013).

\section{Address:}

Elena Ryabina

Karla-Marksa 274

Izhevsk

Udmurt Republic

Russia 426008

Tel: + 79043133677

E-mail: italmas2004@yahoo.de 


\section{References}

Batalova, Raisa M. and Antonina S. Krivoščëkova-Gantman (1985) Komi-permjackorusskij slovar'. Moskva: Russkij jazyk.

Berlin, Brent and Paul Kay (1969) Basic color terms: Their universality and evolution. Berkeley, CA: University of California Press. [Reprinted in 1991.]

Beznosikova, Ljucija M., Evgenija A. Ajbabina and Raisa I. Kosnyreva (2000) Komirusskij slovar'. Syktyvkar: Komi knižnoe izdatel'stvo.

Beznosikova, Ljucija M., Nadežda K. Zaboeva and Raisa I. Kosnyreva (2003) Russko-komi slovar'. Syktyvkar: Komi knižnoe izdatel'stvo.

Biggam, Carole P. (2012) The semantics of colour: A historical approach. Cambridge: Cambridge University Press.

Davies, Ian, Catriona MacDremid, Greville Corbett, Harry McGurk, David Jerrett, Tiny Jerrett, and Paul Sowden (1992) "Color terms in Setswana: A linguistic and perceptual approach”. Linguistics 30, 6, 1065-1103.

Davies, Ian and Greville Corbett (1994) "The basic color terms of Russian". Linguistics 32, 65-89.

Davies, Ian and Greville Corbett (1995) "A practical field method for identifying basic colour terms". Languages of the World 9, 1, 25-36.

Edygarova, Svetlana (2013a) "Ob osnovnyx raznovidnostjax sovremennogo udmurtskogo jazyka”. Ežegodnik finno-ugorskix issledovanij 3, 7-19.

Edygarova, Svetlana (2013b) "O social'nom statuse sovremennyx permskix dialektov". In Voprosy permskoj dialektologii i polevyje issledovanija: tradicii i perspektivy, 53-58. Syktyvkar.

Fletcher, Robert (1980) The City University colour vision test. 2nd ed. London: Keeler.

Kay, Paul (1975) "Synchronic variability and diachronic change in basic color terms". Language and Society 4, 257-270.

Kay, Paul and Chad K. McDaniel (1978) "The linguistic significance of the meanings of basic color terms". Language 54, 3, 610-646.

Kay, Paul, Brent Berlin, and William Merrifield (1991) "Biocultural implication of systems of color naming”. Journal of Linguistic Anthropology 1, 1, 12-25.

Kay, Paul and Luisa Maffi (2009) "Chapter 132-135: Colour Terms". Available online at $<$ http://wals.info/chapter/133>. Accessed on 20.04.2014.

Lytkin, Vasilij I. and Evgenij S. Guljaev (1970) Kratkij ètimologičeskij slovar' komi jazyka. Moskva: Nauka.

MacLaury, Robert E. (1987) "Color-category evolution and shuswap yellow-withgreen". American Anthropologist 89, 1. 107-124.

Paramei, Galina (2005) "Singing the Russian blues: An argument for culturally basic colour terms". Cross-Cultural Research 39, 1, 10-34.

Rakin, Anatolij N. (1990) "Leksika cvetooboznačenija v permskix jazykax". In Paul Alvre, Tiit Kukk, eds. Fenno-Ugristica 16, 112-121. Tartu: Tartu Ülikool. 
Ryabina, Elena (2009) "Sex-related differences in the colour vocabulary of Udmurts". In WEBFU [Wiener elektronische Beiträge des Instituts für Finno-Ugristik]. Available online at $<$ http://webfu.univie.ac.at/texte/12Ryabina.pdf $>$. Accessed on 04.05.2010.

Ryabina, Elena (2011a) Osnovnye cvetooboznačenija v permskix jazykax. Dissertationes Philologiae Uralicae Universitatis Tartuensis, 11. Tartu: Tartu Ülikooli Kirjastus.

Ryabina, Elena (2011b) "Osnovnye cvetonaimenovanija v komi jazyke”. In Jevgenij A. Cypanov, ed. Dinamika struktur finno-ugorskix jazykov, 238-250. Syktyvkar: Kola.

Ryabina, Elena "Osnovnye cvetooboznačenija v komi-permjackom jazyke". In preparation.

Sutrop, Urmas (2001) "List task and a cognitive salience index". Field Methods 13, 3, 263-276.

Sutrop, Urmas (2002) The vocabulary of sense perception in Estonian. (Opuscula Fenno-Ugrica Gottingensia, 8.) Frankfurt am Main: Peter Lang.

Uljašev, Oleg I. (1999) Cvet v predstavlenijax i fol'klore komi. Syktyvkar: Rossijskaja Akademija Nauk, Ural'skoe otdelenie, Komi naučnyj centr.

Waggoner, Terry L. (2002) Quick six colour vision test pseudoisochromatic plates. From Colour vision testing made easy by Good-Lite company.

Wiedemann, Ferdinand Johann (1880) Syrjänisch-deutsches Wörterbuch: nebst einem wotjakisch-deutschen im Anhange und einem deutschen Register. St. Petersburg: Commissionäre der Kaiserlichen Akademie der Wissenschaften.

Elena Ryabina: Laenvärvinimedest komi keeltes. Artiklis võrreldakse vene laenvärvinimesid omavahel lähedalt suguluses olevas sürjakomi ja permikomi keeles. Andmed on kogutud Daviese ja Corbett' (1995) välimeetodiga. Uurimuses on kasutatud 65 standardset Color-aid Corporationi värvitahvlit. Uurimuse eesmärk on laenvärvinimede psühholoogilise esilduvuse väljaarvutamine ja võrdlemine. Tulemused näitavad, et permikomi andmestik sisaldab rohkem laenvärvinimesid. Kognitiivse esiletuleku indeksi järgi on neist psühholoogiliselt esilduvaim zelonej 'roheline'. Põhivärvinimede süsteemi arenedes võivad komi keeltes eeldatavasti leksikaliseeruda koričnevej 'pruun', fioletovej 'lilla' ja oranževej 'oranž', sest need on mõlemas komi keeles kodunenud. Laenvärvinimed rozovyj 'roosa' ja goluboj 'helesinine' ei ole praegusel põhivärvinimede arenguetapil psühholoogiliselt esiletulevad kummaski komi keeles.

Märksõnad: laensõna, põhivärvinimi, psühholoogiline esilduvus, sürjakomi keel, permikomi keel 